\title{
Manifestações audiológicas em crianças e adultos com AIDS******
}

\author{
Audiological manifestations in children and adults with AIDS
}

\author{
Carla Gentile Matas* \\ Valdete Alves Valentins dos Santos Filha** \\ Kleber Ramos de Juan*** \\ Fernanda Rodrigues Pinto**** \\ Isabela Crivellaro Gonçalves*****
}

*Fonoaudióloga. Doutora em Distúrbios da Comunicação Humana pela Universidade Federal de São Paulo (Unifesp). Professora Assistente. Doutora do Curso de Fonoaudiologia do Departamento de Fisioterapia, Fonoaudiologia e Terapia Ocupacional da Faculdade de Medicina da Universidade de São Paulo (FMUSP). Endereço para correspondência: $\mathrm{R}$. Princesa Isabel, 17 - Apto. 204-A - São Paulo - SP - CEP 04601-000

(cgmatas@usp.br).

**Fonoaudióloga. Doutora em Ciências pelo Departamento de Fisioterapia, Fonoaudiologia e Terapia Ocupacional da FMUSP.

***Fonoaudiólogo. Mestre em Ciências pelo Departamento de Fisioterapia, Fonoaudiologia e Terapia Ocupacional da FMUSP.

****Fonoaudióloga. Graduada em Fonoaudiologia pelo Departamento de Fisioterapia, Fonoaudiologia e Terapia Ocupacional da FMUSP.

*****Fonoaudióloga. Doutoranda em Ciências pelo Departamento de Fisioterapia, Fonoaudiologia e Terapia Ocupacional da FMUSP.

******Trabalho Realizado no Departamento de Fisioterapia, Fonoaudiologia e Terapia Ocupacional da FMUSP.

Artigo Original de Pesquisa

Artigo Submetido a Avaliação por Pares

Conflito de Interesse: não

Recebido em 04.09.2009.

Revisado em 23.03.2010; 30.06.2010. Aceito para Publicação em 01.09.2010.

\section{Abstract}

Background: according to the literature, the incidence of hearing impairment in patients with HIV / AIDS might be caused by alterations in external, middle and / or internal ear. Aim: to characterize and to compare the results of audiological assessment and Auditory Brainstem Response in children and adults with AIDS. Method: audiological and electrophysiological (Auditory Brainstem Response) assessment of hearing was carried out in 51 children and 22 adults with HIV/AIDS (research groups I and II, respectively) and in 50 healthy children and 25 healthy adults (control groups I and II, respectively). Participants ranged in age between 3 and 10 years (children) and between 18 and 50 years (adults). Results: the most frequent observed alteration for children with AIDS was related to the middle ear whereas for adults with AIDS it was related to the internal ear. Higher occurrence of abnormal results was observed for adults with AIDS as compared to children with AIDS. Conclusion: children and adults with AIDS present alterations in audiological assessment and Auditory Brainstem Response. This suggests the involvement of peripheral and central auditory pathways. Findings of the present study emphasize the effectiveness of using electrophysiological hearing measures in order to better identify the brain injury level in patients with AIDS, besides allowing the monitoring of the development rate of the disease.

Key Words: Children; Adults; Hearing; ABR; HIV; AIDS.

\section{Resumo}

Tema: a literatura relata a ocorrência de alteração auditiva em pacientes com HIV/AIDS, podendo esta ser decorrente de comprometimentos na orelha externa, média e/ou interna. Objetivo: caracterizar e comparar os resultados da avaliação audiológica e do Potencial Evocado Auditivo de Tronco Encefálico de crianças e adultos com AIDS. Método: foram submetidos à avaliação audiológica e eletrofisiológica (Potencial Evocado Auditivo de Tronco Encefálico) 51 crianças e 22 adultos com AIDS (grupos pesquisa I e II respectivamente) e 50 crianças e 25 adultos saudáveis (grupos controle I e II respectivamente), com idade entre três e 10 anos (crianças) e entre 18 e 50 anos (adultos). Resultados: nas crianças com AIDS foram mais frequentes as alterações de orelha média e nos adultos as de orelha interna, bem como maior ocorrência de resultados alterados no potencial evocado auditivo de tronco encefálico nos adultos quando comparados às crianças. Conclusão: crianças e adultos com AIDS apresentam alterações na avaliação audiológica e no potencial evocado auditivo de tronco encefálico, sugestivas de comprometimento das vias auditiva periférica e central. Os resultados enfatizam a eficácia da utilização dos testes eletrofisiológicos da audição para melhor definição do grau de lesão encefálica em pacientes com AIDS, permitindo ainda a monitorização da velocidade de evolução da doença.

Palavras-Chave: Crianças; Adultos; Audição; PEATE; HIV; AIDS.

Referenciar este material como:

1 Matas CG, Santos Filha VAV, Juan KR, Pinto FR, Gonçalves IC. Audiological manifestations in children and adults with AIDS (original title: Manifestações $\sum 3$ audiológicas em crianças e adultos com AIDS). Pró-Fono Revista de Atualização Científica. 2010 jul-set;22(3):269-74. 


\section{Introduction}

The Acquired Immune Deficiency Syndrome (AIDS) is caused by the human immunodeficiency virus (HIV), a retrovirus that specifically affects the immune system and allows the occurrence of several opportunist infections 1, 2.

The incidence of hearing impairment in patients with HIV/AIDS varies from approximately 20 to $40 \%$ 3-6. The hearing impairment may occur due to problems in the external, middle and/or inner ear. Studies have shown that abnormalities in Auditory Evoked Potentials (AEP) can be observed 4,7-12 before the clinical onset of symptoms such as neurological and cognitive deficits, which all belong to the AIDS dementia complex 13-14. In view of the electrophysiological abnormalities observed in this population, studies have emphasized the importance of AEP in audiological practice in order to identify and treat peripheral and central auditory disorders, both in children as in adults in order to allow an accurate diagnosis of peripheral and central auditory disorders.

The childhood population with HIV/AIDS is affected by the same opportunist infections that infected adult population15. However, studies in the literature refer different clinical outcomes of HIV infection in adults and children. It is known that, in children, the infection becomes more aggressive due to the maturity level of the immune system at the time of virus acquisition. This fact leads to a shorter asymptomatic period, high susceptibility to infection and rapid progression of the disease1516. Taking this into consideration, it becomes important to characterize and to compare the auditory symptoms in children and adults with HIV/ AIDS.

The purpose of this study was to characterize and to compare the results of audiologic and Brainstem Auditory Evoked Potential (BAEP) of children and adults with AIDS.

\section{Method}

This study was conducted at the Auditory Evoked Potentials Research Laboratory of the Department of Physioterapy, Communication Sciences and Disorders and Occupational Therapy of the Medical School, University of São Paulo (Departamento de Fisioterapia, Fonoaudiologia e Terapia Ocupacional da Faculdade de Medicina da Universidade de São Paulo). The study was approved by the Ethical Committee of the Institution, CAPPesq - HC, under protocol number
0642/07. All participants and/or their parents or guardians signed a consent form.

The material of the current study consisted of the results of audiological and Brainstem Auditory Evoked Potential (BAEP) assessments of 51 children and 22 adults with AIDS (research groups I and II, respectively) and 50 healthy children and 25 healthy adults (control group I and II, respectively). All study participants were residents of São Paulo, with black or white skin color, and belonged to families with low or middle income.

For all groups, control I and II and research I and II, the presence of any clinical and/or cognitive impairment that would prevent or hinder the achievement of audiological and/or electrophysiological tests was considered an exclusion criteria. Exclusion criteria for the composition of the research groups were: pregnancy (research group II) and presence of opportunist infections in activity. The sample selection of the control groups was performed through the collection of family and individual history. The exclusion criteria for the composition of these groups were: risk factors for exposure to the virus (perinatal transmission, blood transfusion, injection drug, sexual activity and occupational accident) 1.

The children assessed were aged between 3:0 and 10:11 years. Children in the research group were referred by several institutions, including support homes for children with AIDS. Twenty-two children of this group were male and 29 were female. Children from the control group were referred by an Early Childhood Education and Elementary School. Twenty-nine children from this group were male and 21 were female. Adults assessed were between 18 and 50 years of age. Adults from the study group were referred by the House of AIDS - Zerbini Foundation and the Specialized Municipal Health Services in STD/AIDS of the Municipal Health Secretariat of São Paulo. Fourteen participants were male and eight were female. Adults and children in the research group were recruited based on medical diagnosis of HIV/AIDS. Otological history or complaints were not considered on sample composition. The control group II was composed of volunteer adults who were patrons of the institution where the research was developed.

Information on clinical history of participants was obtained prior to the completion of the audiological and electrophysiological assessment. Information regarding the following possible complaints was obtained: otorrhea, otalgia, ear fullness, tinnitus, noise exposure, hearing loss, ear surgery, use of 
hearing aid device, otitis media, dizziness, sinusitis, rhinitis, allergies, nasal obstruction, etc. The audiological evaluation consisted of the following procedures: inspection of the external auditory canal with a Heine otoscope; audiometry at the frequency range between 500 and $4000 \mathrm{~Hz}$ for children aged from 3:00 to 6:11 years and at the frequency range between 250 and $8000 \mathrm{~Hz}$ for adults and children aged from 7:0 to 10:11 years; speech audiometry. Audiometers GSI 61 and GSI 68 from Grason-Stadler were used. As acoustic impedance measurements, tympanometry and acoustic reflex were performed with the equipment model GSI 33 from Grason-Stadler. Subsequently, the BAEP was performed with the portable equipment Traveler Express from Bio-logic. The acoustic stimulus used to elicit the response was the click with rarefied polarity at an intensity level of $80 \mathrm{dBHL}$, duration of 0.1 milliseconds (ms) and speed of presentation of 19.1 stimuli per second. Values of absolute latencies of waves I, III, V and interpeaks I-III, V, IV were assessed in the analysis of this potential. The BAEP was performed in an electrically protected and acoustically isolated room.

The following were considered normality criteria for the audiological evaluation: presence of hearing thresholds up to $15 \mathrm{~dB}$ HL for children and up to $25 \mathrm{~dB}$ HL for adults, type A tympanometric curve and presence of acoustic reflexes. Altered results were classified into17:

. Conductive Hearing Loss (CHL): presence of difference (GAP) between air (AC) and bone (BC) conduction higher than or equal to $15 \mathrm{~dB} \mathrm{HL}$ - with the $\mathrm{BC}$ lower than or equal to $15 \mathrm{~dB} \mathrm{HL}$ and $\mathrm{AC}$ higher than or equal to $25 \mathrm{~dB}$ HL for adults, and BC lower than or equal to $15 \mathrm{~dB}$ HL and AC higher than or equal to $15 \mathrm{~dB} \mathrm{HL}$ for children in pure tone audiometry; tympanometric curve types B or C; absent or increased acoustic reflexes, respectively; . Sensorineural Hearing Loss (SNHL): absence of air/bone GAP - with the BC higher than or equal to $15 \mathrm{~dB}$ HL and AC higher than or equal to $25 \mathrm{~dB}$ HL for adults, and $\mathrm{AC}$ and $\mathrm{BC}$ higher than or equal to 15 dB HL for children; tympanometric curve type A; present or absent acoustic reflexes according to the degree of hearing loss;

. Mixed Hearing Loss (MHL): conductive and sensorineural components at the same ear.

Latency and interpeaks values of BAEP waves used as reference for the Bio-Logic equipment were used as criteria of normality. Altered results were classified as18:
. low brainstem alteration (LB): normal absolute latency of wave I and interpeak III-V latency and increased latencies of waves III and V and interpeaks I-III and I-V;

. high brainstem alteration (HB): normal absolute latencies of waves I and III and interpeak latency IIII and increased latency of wave $\mathrm{V}$ and interpeaks III-V and I-V;

. both: alterations at both LB and HB;

. suggestive of middle ear involvement: increase of electrophysiological thresholds; delay in absolute latencies of waves I, III and V; and normal interpeaks I-III, III-V and I-V at high intensity;.

. suggestive of sensorineural involvement: increase of electrophysiological threshold and absolute latencies of waves I, III and V; and normal interpeaks I-III, IV and V at high intensity.

\section{Results}

Regarding the results of the audiological assessment of adults and children, it was found that $40.9 \%$ of adults and $27.5 \%$ of children from the research groups presented altered results. No statistically significant differences ( $p$ $=0.256$ ) were observed when comparing the occurrence of normal and altered results between these two populations. No significant alterations were observed in the audiological assessment for the control group.

Table 1 displays the between-groups comparison of the types of alterations observed in basic audiological assessment.

Regarding the research group, there was a significantly higher occurrence of CHL in the group of children when compared to the group of adults ( $\mathrm{p}=$ 0.002). Furthermore, the occurrence of SNHL $(p=0.034)$, as well as MHL ( $p=0.065)$, was significantly higher in adults. The results of BAEP are described in Table 2.

Significantly higher incidence of altered results was observed for the group of adults when compared to the group of children $(p=0.016)$. Little occurrence of altered results was observed in the control group with no statistically significant difference being observed on the comparison between the groups of adults and children ( $p=0.211$ ).

The types of alterations observed in the BAEP are displayed in Table 3.

Children from the research group exhibited higher occurrence of alterations type LB and $\mathrm{HB}$ as well as BAEP alterations that are suggestive of middle ear involvement. Moreover, the alteration type "both", as well as results that are suggestive of sensorineural alteration, were most frequently observed for the group of adults. No statistically significant differences were observed when comparing the groups regarding the occurrence of such alterations. 


\section{Discussion}

A high incidence of hearing impairment is observed in patients with HIV/AIDS. The direct action of the virus, the opportunist infections, and the use of ototoxic drugs are considered possible etiological factors19.

No statistically significant difference was observed when comparing the results of basic audiological assessment of adults and children with AIDS - the majority of participants presented results within normal limits (59.1\% for adults and 72.5\% for children). Moreover, it was evidenced in the current study that children and adults with AIDS presented altered BAEP and audiometric measures (Table 2) with higher frequency than control participants. Similar data were also found in other studies20-21, which suggests that AIDS is a risk factor for peripheral and/or brainstem level hearing loss.

The types of alterations observed in the basic audiological assessment of this population are described in Table 1. We can observe that children with AIDS exhibited higher percentage of conductive hearing loss when compared to the adult population. The sensorineural hearing loss was most frequently presented by the group of adults with AIDS. Therefore, such children as adults with AIDS presented alterations in the audiological assessment. The group of children exhibited a predominance of middle ear involvement and the group of adults exhibited a predominance of inner ear involvement.

In studies with children with HIV/AIDS, some authors have detected the following as main otologic alterations: thickening and retraction of the tympanic membrane (31.8\% of cases); bulging and hyperemia of tympanic membrane $(9.1 \%$ of cases); perforation of the tympanic membrane $(4.5 \%$ of cases); and the existence of neomembrane (4.5\% of cases); all these alterations are possible causes of conductive hearing loss20.

Reports in the literature have evidenced a loss in the auditory function of adults infected by HIV5,22. According to some authors, the hearing loss observed in this population may be conductive or sensorineural, with degree ranging from mild to profound and with no specific configuration - data not discussed in this study5,11-12.

The current findings are consistent with those obtained in a study with 155 adults with AIDS. In that study, the authors found that only $8 \%$ of adults had evidence of chronic otitis media, usually with effusion. The authors also reported that the majority of patients presented moderate, and occasionally
TABLE 1. Comparison of the types of alterations in basic audiological assessment (CHL, SNHL, MHL) between children and adults in control and research groups.

\begin{tabular}{|c|c|c|c|c|}
\hline & & & Control Group & Research Group \\
\hline \multirow{5}{*}{ CHL } & \multirow[t]{2}{*}{ Adults } & $\mathbf{N}$ & 0 & 3 \\
\hline & & $\%$ & 0 & 33,3 \\
\hline & \multirow[t]{2}{*}{ Children } & $\mathbf{N}$ & 0 & 13 \\
\hline & & $\%$ & 0 & 92,9 \\
\hline & \multicolumn{2}{|c|}{ p-value } & -- & $0,002 *$ \\
\hline \multirow{5}{*}{ SNHL } & \multirow[t]{2}{*}{ Adults } & $\mathbf{N}$ & 0 & 4 \\
\hline & & $\%$ & 0 & 44,4 \\
\hline & \multirow[t]{2}{*}{ Children } & $\mathbf{N}$ & 0 & 1 \\
\hline & & $\%$ & 0 & 7,1 \\
\hline & \multicolumn{2}{|c|}{ p-value } & -- & $0,034 *$ \\
\hline \multirow{5}{*}{ MHL } & \multirow[t]{2}{*}{ Adults } & $\mathbf{N}$ & 0 & 2 \\
\hline & & $\%$ & 0 & 22,2 \\
\hline & \multirow[t]{2}{*}{ Children } & $\mathbf{N}$ & 0 & 0 \\
\hline & & $\%$ & 0 & 0,0 \\
\hline & \multicolumn{2}{|c|}{ p-value } & -- & $0,065 *$ \\
\hline
\end{tabular}

Note: CHL - conductive hearing loss; SNHL - Sensorineural Hearing Loss; MHL - Mixed Hearing Loss * p-value statistically significant.

TABLE 2. Comparison of normal and altered results on BAEP between children and adults from control and research groups.

\begin{tabular}{|c|c|c|c|c|c|c|c|c|}
\hline & \multicolumn{4}{|c|}{ Control Group } & \multicolumn{4}{|c|}{ Research Group } \\
\hline & \multicolumn{2}{|c|}{ Adults } & \multicolumn{2}{|c|}{ Children } & \multicolumn{2}{|c|}{ Adults } & \multicolumn{2}{|c|}{ Children } \\
\hline & $\mathbf{N}$ & $\%$ & $\mathbf{N}$ & $\%$ & $\mathbf{N}$ & $\%$ & $\mathbf{N}$ & $\%$ \\
\hline Normal & 23 & 92,0 & 49 & 98,0 & 8 & 36,4 & 34 & 66,7 \\
\hline Altered & 2 & 8,0 & 1 & 2,0 & 14 & 63,6 & 17 & 33,3 \\
\hline p-value & \multicolumn{4}{|c|}{0,211} & \multicolumn{4}{|c|}{ 0,016* } \\
\hline
\end{tabular}

Note: * p-value statistically significant.

TABLE 3. Comparison of the types of BAEP alterations (LB, HB, both, suggestive of ME, suggestive of SN) between children and adults from control and research groups.

\begin{tabular}{|c|c|c|c|c|}
\hline & & & $\begin{array}{c}\text { Control } \\
\text { Group }\end{array}$ & Research Group \\
\hline \multirow{5}{*}{ Low Brainstem } & Adults & $\mathbf{N}$ & 0 & 4 \\
\hline & & $\%$ & 0 & 28,6 \\
\hline & \multirow{2}{*}{$\begin{array}{c}\text { Childre } \\
\text { n }\end{array}$} & $\mathbf{N}$ & 0 & 6 \\
\hline & & $\%$ & 0 & 35,3 \\
\hline & \multicolumn{2}{|c|}{ p-value } & -- & 0,690 \\
\hline \multirow{5}{*}{ High Brainstem } & Adults & $\mathbf{N}$ & 0 & 1 \\
\hline & & $\%$ & 0 & 7,1 \\
\hline & Childre & $\mathbf{N}$ & 1 & 2 \\
\hline & $\mathbf{n}$ & $\%$ & 100 & 11,8 \\
\hline & \multicolumn{2}{|c|}{ p-value } & 0,083* & 0,665 \\
\hline \multirow{5}{*}{ Both } & Adults & $\mathbf{N}$ & 0 & 3 \\
\hline & & $\%$ & 0 & 21,4 \\
\hline & Childre & $\mathbf{N}$ & 0 & 1 \\
\hline & $\mathbf{n}$ & $\%$ & 0 & 5,9 \\
\hline & \multicolumn{2}{|c|}{ p-value } & -- & 0,199 \\
\hline \multirow{5}{*}{$\begin{array}{c}\text { Suggestive of } \\
\text { ME }\end{array}$} & Adults & $\mathbf{N}$ & 2 & 4 \\
\hline & & $\%$ & 100 & 28,6 \\
\hline & Childre & $\mathbf{N}$ & 0 & 8 \\
\hline & $\mathbf{n}$ & $\%$ & 0 & 47,1 \\
\hline & \multicolumn{2}{|c|}{ p-value } & 0,083* & 0,293 \\
\hline \multirow{5}{*}{ Suggestive of SN } & Adults & $\mathbf{N}$ & 0 & 2 \\
\hline & & $\%$ & 0 & 14,3 \\
\hline & \multirow{2}{*}{$\begin{array}{c}\text { Childre } \\
\text { n }\end{array}$} & $\mathbf{N}$ & 0 & 0 \\
\hline & & $\%$ & 0 & 0 \\
\hline & \multicolumn{2}{|c|}{ p-value } & -- & 0,107 \\
\hline
\end{tabular}

Note: LB: Low Brainstem; HB: High Brainstem; ME: middle ear; SN: Sensorineural; * p-value statistically significant. 
severe, sensorineural hearing loss, besides low and high frequencies being more altered than middle frequencies 22. Other authors 12,19,23 have reported sensorineural hearing loss at high frequencies as the most common finding in the assessment of HIV-infected individuals.

Currently, it is known that the nervous and immune systems are the main targets of HIV infection. The neurological manifestations directly related to HIV include the involvement of the peripheral nervous system and there is evidence of a direct relationship among neurological complications, stage of HIV infection and level of immunologic involvement 24.

When comparing the occurrence of normal and altered BAEP results of adults and children with AIDS from the current study, a statistically significant higher incidence of altered results was observed for the group of adults (Table 2).

Several studies in the literature emphasize that abnormalities in BAEP are among the electrophysiological manifestations directly attributable to HIV infection8-11,25. These authors highlight that the electrophysiological alterations observed are mainly related to alterations in the synchrony of the generation of neuroelectric impulses along the auditory pathway at the brainstem level.

There was variability with respect to the types of BAEP alterations found in both groups (Table 3). Likewise, one can observe in the literature, the

\section{Conclusion}

Children and adults with HIV/AIDS present alterations in the audiological and brainstem auditory evoked potentials assessment that are suggestive of impairment of peripheral auditory pathway, being that: great diversity of BAEP tracings of individuals with HIV/AIDS. This reveals auditory pathway impairments such at the low as at the high brainstem, that is, a diffuse involvement of the auditory pathway at the brainstem level4,9,11,25-28. In the current study, although children with AIDS presented a lower index of auditory brainstem alterations as compared to the adult population, alterations at the lower brainstem were most frequently observed in both groups, confirming data described in literature9.

Still regarding the BAEP, it was observed that the findings suggestive of middle ear involvement were more frequent in children whereas findings suggestive of sensorineural hearing impairment were more common in adults (Table 3 ). This is consistent with the results presented for the basic audiological assessment.

Alterations on peripheral and central auditory pathways are precociously observed in the population with AIDS. Therefore, the importance of audiological and electrophysiological investigation of hearing in individuals infected with HIV is highlighted. The audiological monitoring allows early identification of hearing impairments and supports, this way, the rehabilitation process and a proper orientation of patients and families29. Findings of this study emphasize the effectiveness of electrophysiological measures on the better definition of the degree of brain injury in patients with AIDS and allow the monitoring of the disease progression.

. children exhibit conductive hearing loss more often than adults do due to middle ear disorders; . adults exhibit sensorineural hearing loss more often than children do due to inner ear disorders; - adults exhibit higher incidence of altered brainstem auditory evoked potentials, that is auditory pathway impairment at the brainstem level, when compared to children. 


\section{References}

1. Friedland GH, Klein RS. Transmission of the human immunodeficiency virus. $\mathrm{N}$ Engl J Med. 1987; 317(18):1125-35.

2. Chow KY, Ang LW, Verghesse I, Chew SK, Leo YS. Measurable predictive factors for progression to AIDS among HIV-infected patients in Singapore. Ann Acad Med. 2005;34(1):84-9.

3. Chandrasekhar SS, Connelly PE, Brahmbhatt SS, Shah CS, Kloser PC, Baredes S. Otologic and audiologic evaluation of human immunodeficiency virus-infected patients. Am J Otolaryngol. 2000;21(1):1-9.

4. Mata Castro N, Yebra Bango M, Tutor de Ureta P, Villarreal Garcia-Lomas M, Garcia Lopez F. Hearing loss and human immunodeficiency virus infection. Study of 30 patients. Rev Clin Esp. 2000;200(5):271-4.

5. Khoza K, Ross E. Auditory function in a group of adults infected with HIV/AIDS in Gauteng, South Africa. S Afr J Commun Disord. 2002;49:17-27.

6. Prasad HKC, Bhojwani KM, Shenoy V, Prasad SC. HIV manifestation in otolaryngology. Am J Otolaryngol - Head Neck Med Surg. 2006;179-85.

7. Birchall MA, Wight RG, French PD, Cockbain Z, Smith SJ. Auditory function in patients infected with the human immunodeficiency virus. Clin Otolaryngol. 1992;17(2):117-21.

8. Bankaitis AE, Keith RW. Audiological changes associated with HIV infection. Ear Nose Throat J. 1995;74(5):353-9.

9. Bankaitis AE, Christensen LA, Murphy G, Morehouse CR. HIV/AIDS and auditory evoked potentials. Seminars in Hearing. 1998;19(2):177-93.

10. Matas CG, de Juan KR, Nakano RA. Middle and late latency auditory evoked potentials in adults with AIDS. Pro Fono. 2006b;18(2):171-6.

11. Silva AC, Pinto FR, Matas CG. Audiological and electrophysiological evaluation of children with acquired immunodeficiency syndrome (AIDS). Braz J Infect Dis. 2007;10(4):264-8.

12. Matas CG, Marcon BA, Silva SM, Gonçalves IC. Avaliação auditiva na síndrome da imunodeficiência adquirida. Rev Soc Bras Fonoaudiol. In press.

13. Smith T, Jakobsen J, Gaub J, Helweg-Larsen S, Trojaborg W. Clinical and electrophysiological studies of human immunodeficiency virus - soropositive men without AIDS. Ann Neurol. 1988;23:295-7.

14. Ollo C, Johnson R, Grafman J. Signs of cognitive change in HIV disease: an event-related brain potential study. Neurology 1991;41:209-15

15. Sculerati N, Borkowsky W. Pedriatric human immunodeficiency virus infection: an otolaryngologist's perspective. J Otoryngol. 1990;19(3):182-8.

16. Peckham C, Gibb D. Mother-to-child transmission of the human immunodeficiency virus. N Engl J Med. 1995; 333(5):298-302.
17. Momensohn-Santos TM, Russo ICP, BrunettoBorgianni LM. Interpretação dos Resultados da Avaliação Audiológica. In: Momensohn-Santos TM, Russo ICP. A Prática da Audiologia Clínica. 5a ed. São Paulo: Cortez. 2005. p. 291-310.

18. Matas CG. Medidas Eletrofisiológicas da audição Audiometria de Tronco encefálico. In: Carvallo RMM. Fonoaudiologia informação para a formação Procedimentos em Audiologia. Rio de Janeiro: Guanabara Koogan. 2003. p. 43-57.

19. Roland Jr JT, Alexiades G, Jackman AH, Hillman D, Shapiro W. Cochlear Implantation in Human Immunodeficiency Virus - Infected Patients. Otol \& Neurotol. 2003;24(6):892-5.

20. Martins RHG, Batista L, Souza ACV, Costa GA, Zuliani A, Neto JO. Manifestações otorrinolaringológicas em crianças com AIDS. Rev Bras Otorrinolaringol. 2001;67 (2):204-11.

21. Matas CG, Leite RA, Magliaro FCL, Gonçalves IC. Audiological and Electrophysiological Evaluation of Children with Acquired Immunodeficiency Syndrome (AIDS). Braz J Inf Dis. 2006;10(4):264-8.

22. Soucek S, Michaels L. The ear in the acquired immunodeficiency syndrome: II. Clinical and audiologic investigation. Am J Otol. 1996;17(1):35-9.

23. Matas CG, Sansone AP, Iório MCM, Succi RCM. Avaliação audiológica em crianças nascidas de mães soropositivas para o vírus da imunodeficiência humana. Rev Bras Otorrinolaringol. 2000;66(4):317-24.

24. Almeida SM, Letendre S, Ellis R. Human Immunodeficiency Virus and the Central Nervous System. Braz J Inf Dis. 2006;10(1):41-50.

25. Matas CG, Silva SM, Marcon BA, Gonçalves IC. Electrophysiological manifestations in adults with HIV/ AIDS submitted and not submitted to antiretroviral therapy. Pró-Fono Revista de Atualização Científica. 2010;22(2):107-12.

26. Hart CW, Cokely CG, Schupbach J, Dal Canto MC Coppleson LW. Neurologic finding of a patient with acquired immune deficiency syndrome. Ear Hear. 1989;10(1):6876.

27. Pierelli F, Garrubba C, Tilia G, Parisi L, Fattaposta F, Pozzessere G, Soldati G, Stanzione P, D'Offizi G, Mezzaroma I. Multimodal evoked potentials in HIV-1 seropositive patients: relationship between the immune impairment and the neurophysiological function. Acta Neurol Scand. 1996; 93(4):226-71.

28. Castello E, Baroni N, Pallestrini E. Neurotological auditory brain stem response findings in human immunodeficiency virus- positive patients without neurologic manifestation. Ann Otol Rhinol Laryngol. 1998; 107(12):1054-60.

29. Goffi-Gomez MVS, Liberman PHP, Gonçalves IC, Schultz C. Audiologic Consequences of Ototoxicity: case Report with Deterioration of the Intelligibility of Speech. Applied Cancer Research. 2009;29(2):95-9. 